\title{
Kroz pustinju i prašumu
}

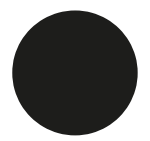

Južna ozvezdja: poetike neuvrščenih, Muzej sodobne umetnosti Metelkova, Ljubljana, 7. ožujka -10. rujna 2019.

DOI: $10.31664 / z u .2019 .104 .11$

Iz današnje perspektive posttranzicijskog pustošenja, robovanja diktatu međunarodnih financijskih institucija i zombijskog plesa prema koreografiji nevidljive ruke neoliberalnog tržišta, politički projekt moderne države sa svim svojim emancipacijskim dimenzijama i unatoč svim svojim unutrašnjim protuslovljima (i konačnom krahu) još uvijek predstavlja konstantan izvor ideja za razmišljanje o alternativama sadašnjosti. Nije ni čudo. Iz pozicije u kojoj se nalazimo danas obje verzije modernoga političkog projekta, i „istočna” socijalistička i „zapadna” welfare state, djeluju kao epohalni civilizacijski doseg koji nam je prelako iskliznuo iz ruku i koji moramo ponovno promisliti ne bismo li pokušali naći izlaz iz neoliberalnog kotla sadašnjosti u kojem se politika čini nemogućom. Pritom bez sumnje riskiramo zanemarivanje barem dijelom radikalno različitog konteksta, odnosno različitih okolnosti i preduvjeta-kako ono bješe, prošlost je druga zemlja-što čini takve pokušaje promišljanja prošlih političkih projekata istodobno nužnima i skliskima.

$\rightarrow$ 


\section{In Desert and Wilderness}

O

Southern Constellations: The Poetics of the Non-Aligned, Museum of Contemporary Art Metelkova, Ljubljana, March 7 -September Io, 2019

DOI: 10.31664/zu.2019.104.11

From today's perspective of post-transitional devastation, servitude to international financial institutions and zombie dancing to the choreography of the neoliberal market's invisible hand, the political project of the modern state, with all its emancipatory dimensions and despite all its inner contradictions (and ultimate collapse) still represents a constant source of ideas for thinking about the alternatives of today. And no wonder. From the position in which we are currently in, both versions of the modern political project, the "eastern" socialist as well as the "western" welfare state, seem like an epochal civilizational achievements that slipped out of our hands too easily, and which we must rethink in order to find a way out from the neoliberal cauldron in which politics seems impossible. In doing so, we doubtlessly risk ignoring at least part of a radically different context, or rather different circumstances and preconditions-how does that saying go, the past is a foreign country - which make such attempts at investigating past political projects both necessary and slippery.

$\rightarrow$ 
Jedna je od takvih epizoda opjevani jugoslavenski vanjskopolitički projekt nesvrstanih, već pomalo kultni primjer političke alternative polarizacijama svijeta i imperijalističkim pretenzijama i pritiscima. Pokret nesvrstanih, osnovan u Beogradu u žiži hladnog rata 1961. godine, ubrzo postaje glavna vanjskopolitička pozicija jugoslavenske države. Utemeljen na načelima neblokovskih podjela i međunarodnog sudjelovanja na vrijednostima jednakopravnosti država te emancipacije zemalja u razvoju, pokret neko vrijeme djeluje kao relevantna politička sila, koja je Jugoslaviji donijela znatan vanjskopolitički, ali i ekonomski i kulturni utjecaj. I upravo je taj moment, kao model stvaranja međunarodnih kulturnih mreža na antikolonijalnim i protuimperijalističkim osnovama, u središtu zanimanja kustosice ljubljanskog Muzeja suvremene umjetnosti (MG+MSUM) Bojane Piškur i izložbe Južne konstelacije. Kompleksno opredijeljena izložba propituje nasljeđe Pokreta nesvrstanih iz više problemskih perspektiva i kroz različite temporalnosti, od dokumentarnog pogleda na sam pokret i implikacija kulturno-umjetničke suradnje unutar njega, preko preispitivanja samoga modernizma u različitosti njegovih konteksta i artikulacija, do doticanja unutarnjih paradoksa samoga pokreta i njegovih parola. Izložba je, barem na prvi pogled, postavljena kronološki, što se na trenutak može činiti kao neambiciozan izbor, ali je zapravo-i to je svakako jedan od njezinih najboljih trenutaka-svaki njezin dio istodobna refleksija problematike iz različitih vremenskih perspektiva, kako one prošlosti tako i one sadašnjosti, a ponekad i potencijalnih budućnosti.

Ulaskom na izložbu nailazimo na pomalo očekivane, u MG+MSUM-u vrlo česte, dokumentarne kontekstualizacije, ovdje prisutne u obliku fotografija prvog susreta nesvrstanih 1961. u Beogradu, na koje se nadovezuju ekskursi u vidu dva trofejna primjera kulturne razmjene Pokreta nesvrstanih: jedan je ljubljanski Grafički bijenale, drugi podgorička Galerija umjetnosti nesvrstanih zemalja. Već tu postaje jasna ambicija izložbe da temeljito promisli prevođenje političkih premisa pokreta u stvaranje kulturnih mreža, posebice u pogledu formuliranja čvrstih pozicija kako u relaciji prema univerzalističkom diktatu zapadnoga modernističkog diskursa tako i prema „provincijaliziranim modernizmima” u različitim situacijama nesvrstanih država. I upravo je ljubljanski Grafički bijenale fenomen koji materijalizira tu diskrepanciju. Bijenale je utemeljio 1954. godine tadašnji direktor Moderne galerije Zoran Kržišnik u cilju otvaranja jugoslavenske umjetnosti stranim utjecajima i nadilaženja polarizacija hladnog rata. No pokazalo se da su Kržišnika zanimali prije svega utjecaji Zapada, što je bilo očito već prema proceduri selekcije: na jednoj strani vršio ju je međunarodni žiri sastavljen od uglavnom zapadnih kustosa i kritičara, čime su izložbe dobivale najprominentnije sudionike, opet uglavnom one iz Zapadnog kanona; drugi dio selekcije vršio se direktnim pozivom državama, bez miješanja u odabir, što je bio dominantni način sudjelovanja za članice Pokreta nesvrstanih. Kad uzmemo u obzir i manje reprezentativno tretiranje tih radova unutar same izložbe, postaje jasno da su (povijesno) umjetnička i politička agenda predstavljale posve divergentne motivacije. Taj nedostatak promišljenijeg stava prema alternativnim artikulacijama modernizma, barem u pogledu njegove kulturne dimenzije, moment je na koji izložba Južne konstelacije na više mjesta upozorava kao na jedan od ključnih problema pokreta. I zaista, pogledom na fragmente iz drugih sličnih epizoda iz povijesti kulturnih mreža pokreta, kao što su podgorička Galerija umjetnosti nesvrstanih zemalja ili serija međunarodnih izložbi u Umjetničkom paviljonu u Slovenj Gradcu, teško se možemo oteti dojmu da i mi, kao baštinici jugoslavenskoga kulturnog prostora, nemamo drugih mehanizama vrednovanja tog umjetničkog korpusa do utvrđivanja mjere njegove sukladnosti zapadnom modernističkom kanonu. Južne konstelacije suptilno nas suočavaju s tim vakuumom nudeći paralelno čitanje političkog kreda i nespremnosti za njegovu primjenu u transformaciji umjetničkog diskursa jugoslavenskog modernizma, odlučno zagledanog prema Zapadu. Zato i pomalo iznenađuje pojavljivanje Gorgone na toj izložbi, točnije rada Đure Sedera. Taj insert prati tekst Nade Beroš koji objašnjava kontekst: riječ je zapravo o predstavljanju Gorgone na izložbi Contemporary Art of the Non-Aligned 
One of such episodes was the celebrated Yugoslav foreign policy project of NonAligned countries, by now a somewhat legendary example of a political alternative to global polarisations and imperialist pretensions and pressures. The NonAligned Movement (NAM), founded in Belgrade in I96I, at the height of the Cold War, soon became the main foreign policy position of the Yugoslav state. Based on the principles of anti-block politics and international cooperation according to the values of the equality of states and the emancipation of developing countries, for a while the Movement represented a relevant political power which earned Yugoslavia significant influence in foreign policy, as well as the economic and cultural sphere. It is precisely that moment, as the model for creating international cultural networks on anti-colonial and anti-imperialistic foundation, which is at the centre of interest of the Ljubljana Museum of Contemporary Art (MG+MSUM) curator Bojana Piškur and the Southern Constellations exhibition. A complexly oriented exhibition questions the legacy of the Non-Aligned Movement from multiple problem perspectives and different temporalities, from the documentary view of the Movement itself and the implications of the cultural-artistic cooperation within it, through a reconsideration of modernism in the diversity of its contexts and articulations, to addressing the inner paradoxes of the Movement and its slogans. The exhibition, at least at first glance, was set up chronologically, which at first might seem like an unambitious choice, but actually - and this is definitely one of its best moments - each part represents a simultaneous reflexion on the issue from different temporal perspectives, the past as well as the present, and sometimes even the potential futures.

Upon entering the exhibition, we find the somewhat expected, at MG+MSUM very frequent documentary contextualisations, here present in the form of photographs of the first meeting of non-aligned countries in I96I in Belgrade, followed by digressions in the shape of two trophy examples of NAM's cultural exchange: one is the Ljubljana Biennial of Graphic Arts, and the other the Gallery of the NonAligned Countries in Podgorica. Now the show's ambition becomes clear: to thoroughly investigate the conveying of the Movement's political premises into the formation of cultural networks, especially with regard to formulating firm positions, both in relation to the universalist dictate of western modernist discourse as well as to "provincialized modernisms" in varying conditions of the non-aligned countries. And the Ljubljana Biennial of Graphic Arts was the very phenomenon that materialised this discrepancy. The Biennial was founded in 1954 by the then manager of the Modern Gallery Zoran Kržišnik, with the aim of opening Yugoslav art up to foreign influences and overcoming the polarisations of the Cold War. However, it turned out that Kržišnik was primarily interested in influences from the West, which already became obvious from the selection procedure: one part of it was conducted by an international jury made up of mostly western curators and critics, which ensured that the exhibition would have the most prominent participants, again mostly from the Western cannon; the second part of the selection was done by direct invitations to participating countries, without any interference in their choice, which was the dominant method of participation for Non-Aligned countries. When we also take into account the less representative treatment of those works within the exhibition itself, it becomes clear that the (historical-)artistic and political agendas represented completely divergent motivations. This lack of a more deliberate attitude toward alternative articulations of modernism, at least with regard to its cultural dimension, is something that the Southern Constellations exhibition raises in several places as one of the key problems of the Movement. Sure enough, if we look at the fragments of other, similar episodes from the history of the Movement's cultural networks, such as the Gallery of NonAligned Countries in Podgorica or a number of international exhibitions in the Art Pavilion in Slovenj Gradec, we cannot help feeling that, as inheritors of the Yugoslav cultural space, we do not have other mechanisms for evaluating this artistic corpus except to establish the degree of its compatibility with the Western modernist cannon. Southern Constellations subtly confront us with this vacuum by 


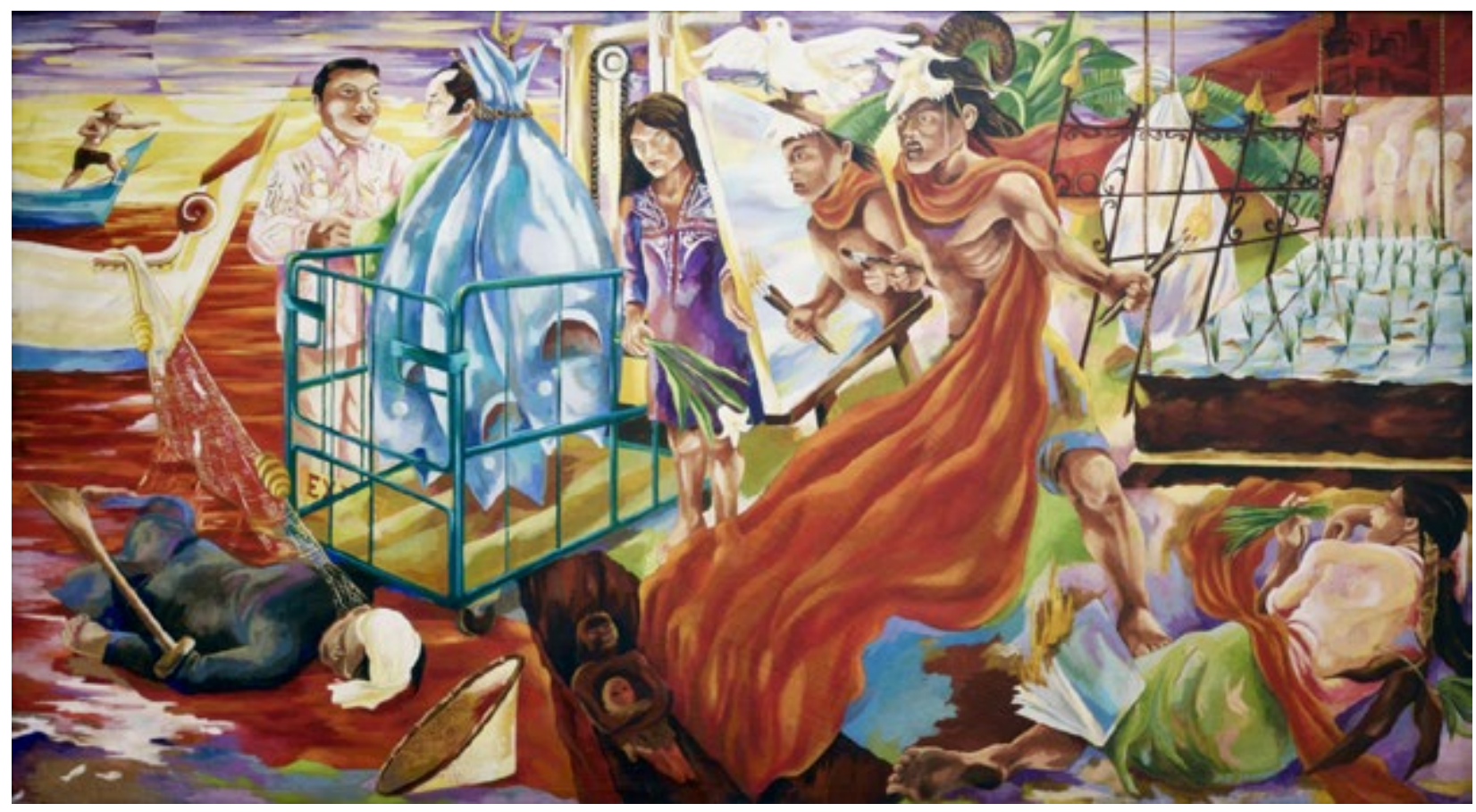




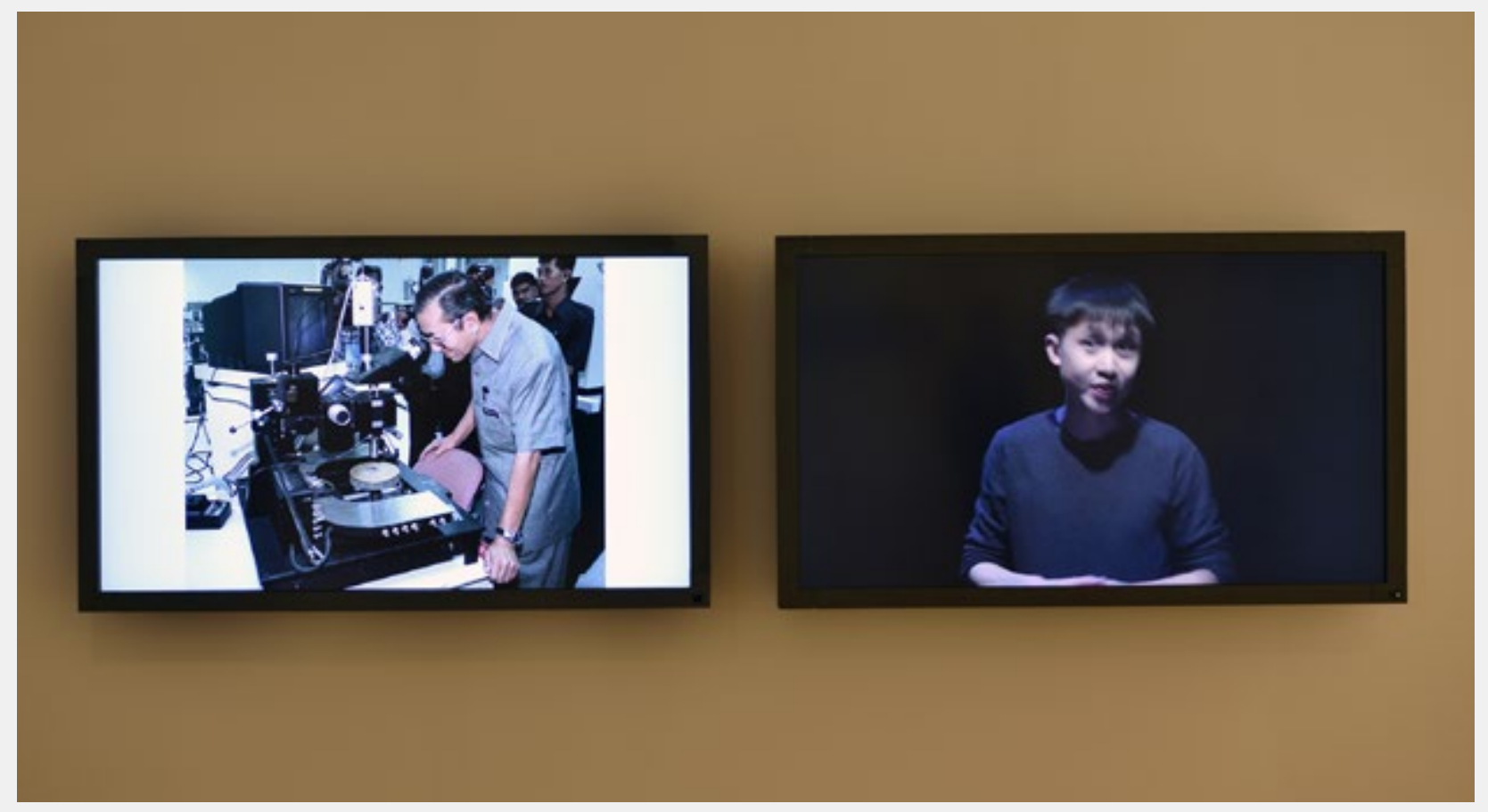


Countries sredinom devedesetih, svojevrsnom sižeu umjetnosti država članica post festum. Beroš je time htjela povući paralelu između neuvrštavanja Gorgone na ideološkoj osnovi i samog Pokreta nesvrstanih, ali se ta paralela ipak čini prilično isforsirana ima li se u vidu činjenica da je Gorgona u svojoj prepoznatljivoj antipolitičkoj gesti nastupala upravo protiv lažnog optimizma političkih parola moderne države, čiji neuspjeh rano prepoznaje.

Bez obzira na upravo spomenuto, izložba Južne konstelacije kompleksno je tkivo koje u svakome svojem dijelu sučeljava razmišljanja o kulturnim implikacijama Pokreta nesvrstanih s njegovim političkim i ekonomskim dimenzijama. Istodobno se u tim sučeljavanjima, i to je svakako jedan od njezinih aduta-ocrtava genealogija raspada emancipacijskoga modernog političkog projekta i njegov konačni poraz u neoliberalizmu. To rječito prikazuju različiti spretno upleteni umjetnički radovi, kao što su dvokanalna videoinstalacija Hoa Ruija Ana ili arhivski kolaži Dubravke Sekulić, koji prate transformacije jugoslavenskoga građevinskog poduzeća Energoprojekt. Osobito mjesto na izložbi zauzima, i po ambiciji i po opsegu, monumentalna trokanalna videoinstalacija Naeema Mohaiemena Dva susreta $i$ pogreb, koja sondira unutarnje napetosti i paradokse pokreta, koje su bitno pridonijele njegovoj razgradnji. To su radovi koji, među ostalim, zatvaraju krug koji vodi od kraha predratnih kolonijalnih sila, preko široke fronte antikolonijalnih gibanja i fenomena, u čijem su mozaiku kamenčić i nesvrstani, do njihove razgradnje i uspona neoliberalizma kao svojevrsnog vrhunca i dovršetka kolonijalizma u neslućenim razmjerima.

To nas dovodi i do raznih fenomena aktualnog trenutka koje izložba adresira bez pretjerane didaktičnosti. Dok gledamo razglednice koje su radnici jugoslavenskih poduzeća slali rodbini iz raznih egzotičnih krajeva univerzuma nesvrstanih postajemo svjesni da izgovaranje tih toponima danas zvuči kao litanija kriznih žarišta iz posljednjih vijesti. Izvrsni dokumentarni materijali iz ostavštine Stevana Labudovića, službenog Titova snimatelja iz rovova alžirskog rata za nezavisnost (dijelom obrađenih u dokumentarcu Mile Turajlić) djeluju pak kao paradoksni podsjetnici na nedavne suprotne, imperijalističke intervencije širom arapskog svijeta. Slično je i s problematikom migracija, odnosno migrantske krize koja je netendenciozno na izložbi prisutna u radovima Godfrieda Donkora, koji od vezilja iz Gane naručuje izvezivanje europskih povijesnih grbova s heraldičkim likom crnačke, odnosno saracenske glave na stranice novina Financial Times, i Aye Haidar, koja je na različite podloge izvezla slike osobnih stvari koje su ponijeli izbjegli iz Sirije i onih za njihovu samosvijest važnih predmeta koje su bili prisiljeni ostaviti za sobom.

Izložbeni postav završava s nekoliko sjajnih radova, koji sumiraju paradokse pokreta i suočavaju nas s (ne)mogućnošću reartikulacije njegova nasljeđa. Eklektična pseudoorijentalistička tipografija Babija Badalova igra se riječju east, tim u političkom žargonu modernosti opterećenim terminom. Dok je Pokret nesvrstanih predstavljao šansu da se „istok” oslobodi mrlje neprestanog kaskanja u modernizaciji i postavi vlastite uvjete puta u modernost, east iz Badalovljevih tipografija dospijeva u nesretne kombinacije, ponovno postajući sad-east, extreme-east, capital-east. Pomalo romantični patos lišen patetike cijeloj priči daje odlična Katarina Zdjelar u videu Moj život (Malaika), u kojem ganski državni orkestar izvodi antikolonijalnu budnicu Malaika. No u njihovu izvođenju nema ništa budničkog; umorna lica glazbenika, njihovi natučeni instrumenti te posebno izvedba u pogrešnom tempu i tonalitetu znaci su nekoga neuspjelog projekta, emancipacijskog projekta koji se nikad nije suočio sa svojom eurocentričnom premisom. Unatoč opisanom zaključku, izložba Južne konstelacije ipak nije defetistička. Doduše, uzalud ćemo tražiti konkretnije recepte za oživljavanje modela međunarodne kooperacije na temeljima načela nesvrstanih. Naprotiv, umjesto pojednostavljenih reanimacija, Južne konstelacije nude ozbiljnu refleksiju premisa i unutarnjih paradoksa pokreta koji su zasigurno pridonijeli njegovu neuspjehu. Priča 
offering a parallel reading of the political creed and the unwillingness to implement it in the transformation of Yugoslav modernism's artistic discourse, which is firmly focused towards the West. That is why it is somewhat surprising to see that the exhibition features the Gorgona group, or more accurately the work of Đuro Seder. That insert is accompanied by Nada Beroš's text which explains the context: it is a matter of presenting the presentation of the Gorgona group at the mid-I990s exhibition Contemporary Art of the Non-Aligned Countries, a sort of a summary of art in the member states delivered post festum. Beroš thus wanted to draw a parallel between the nonalignment of the Gorgona group on the ideological basis and the Non-Aligned Movement itself, but that parallel seems quite forced if one bears in mind that, in its recognisably anti-political gesture, Gorgona stood against precisely this kind of fake optimism of political slogans of the modern state, whose failure it recognised early on.

Regardless of everything mentioned, the Southern Constellations exhibition is a complex organism whose every part squares off ideas about the cultural implications of the Non-Aligned Movement with its political and economic dimensions. At the same time, and this is definitely one of its advantages, these confrontations outline the genealogy of the collapse of the emancipatory modern political project and its final defeat in neoliberalism. This is eloquently demonstrated by different, skilfully interlaced art works, such as the two-channel video installation by Ho Rui An or Dubravka Sekulić's archival collages, which follow the transformations of Yugoslav construction company Energoprojekt. A special place in the exhibition, both by its ambition and its scale, is held by the monumental three-channel video installation by Naeem Mohaiemen, Two meetings and a funeral, which sounds the inner tensions and paradoxes of the Movement that significantly contributed to its disintegration. These are some of the pieces which close the circle that leads from the collapse of pre-war colonial powers, through a wide front of anticolonial movements and phenomena - in the mosaic of which the Non-Aligned were a pebble - to its disintegration and the rise of neoliberalism as a sort of an apex and finalisation of colonialism on an unimagined scale.

This further brings us to the different phenomena of the current moment which the exhibition addresses without excessive didacticism. While looking at postcards that the workers of Yugoslav companies sent to their relatives from various exotic corners of the Non-Aligned universe, we realise that saying those toponyms out loud today sounds like a litany of crisis hotspots from the latest news reports. Excellent documentary material from the heritage of Stevan Labudović, Tito's official photographer from the trenches of the Algerian independence war (partly covered in the documentary by Mila Turajlić), acts as a paradoxical reminder of the recent opposite, imperialist interventions throughout the Arab world. Similarly present is the issue of migration, or rather of the migrant crisis that is untendentiously represented by the work of Godfried Donkor, who had embroiderers from Ghana make historical European coats of arms with a heraldic image of a black, or rather Saracen head on the pages of the Financial Times, and Aya Haidar, who embroidered different surfaces with images of personal objects taken by refugees from Syria, and those items - important for their self-possession - which they were forced to leave behind.

The exhibition ends with several great pieces that summarise the paradoxes of the Movement and confront us with the (im)possibility of rearticulating its legacy. The eclectic pseudo-orientalist typography of Babi Badalov plays with the word "east," this - in the political jargon of modernity-laden term. While the Non-Aligned Movement represented a chance for the "east" to free itself from incessantly lagging behind in terms of modernisation, and to set its own terms for the path to modernity, the "east" from Badalov's typographies ends up in unfortunate combinations, becoming sad-east, extreme-east, capital-east. A somewhat romantic pathos, devoid of sentimentalism, is provided by the brilliant Katarina Zdjelar in the 
o nesvrstanima tako postaje konkretiziran narativ naše modernosti, obećanja emancipacije i njegove deziluzije. Istodobno nam tako uspostavljena crvena linija izložbe pokazuje našu neoliberalnu sadašnjost ne kao „splet nesretnih okolnosti”, već kauzalitet političkih odabira za koje moramo preuzeti odgovornost.

- 
video My Lifetime (Malaika), in which the Ghanaian state orchestra performs the anti-colonial patriotic song Malaika. But there is nothing combative in their interpretation; tired faces of the musicians, their battered instruments and especially the performance in the wrong tempo and tonality are signs of an unsuccessful project, an emancipatory project that never faced its Eurocentric premise. Despite this conclusion, the Southern Constellations exhibition is not defeatist. To be sure, a search for more concrete recipes for reanimating the model of international cooperation on the basis of the principles of the Non-Aligned would be in vain. On the contrary, instead of simplified reanimations, the Southern Constellations offers a serious reflexion on the premises and inner paradoxes of the Movement which surely led to its failure. The story of the Non-Aligned thus becomes a concretized narrative of our modernity, promises of emancipation and their disillusionment. At the same time, the red line that has been set up by the exhibition shows us our neoliberal reality, not as a "web of unfortunate circumstances," but as the causality of political choices for which we must take responsibility. 